\title{
Bioactivity of medicinal plant extracts against human fungal pathogens and evaluation of toxicity using Vero cells
}

\author{
Oon, Y.N. ${ }^{1}$, Chen, R.J. ${ }^{1}$, Kuan, J.M. ${ }^{1}$, Sit, N.W. ${ }^{1 *}$ \\ ${ }^{1}$ Department of Allied Health Sciences, Faculty of Science, Universiti Tunku Abdul Rahman, Bandar Barat, 31900 Kampar, Perak, Malaysia \\ *Corresponding author: sitnw06@gmail.com; sitnw@utar.edu.my
}

\section{ARTICLE HISTORY}

Received: 25 October 2020

Revised: 18 September 2021

Accepted: 18 September 2021

Published: 30 September 2021

\begin{abstract}
Medicinal plants are a potential source of new antifungal agents to combat the development of drug-resistant fungi. This study aims to investigate the aerial parts of Alternanthera sessilis (Amaranthaceae) and Ipomoea aquatica (Convolvulaceae), and the leaves of Catunaregam spinosa (Rubiaceae) and Tradescantia spathacea (Commelinaceae) for antifungal activity and cytotoxicity. The plant materials were extracted sequentially using hexane, chloroform, ethyl acetate, ethanol, methanol, and distilled water. The antifungal activity was evaluated against four species of yeasts and two species of filamentous fungi using a colorimetric broth microdilution method. The toxicity of the extracts was assessed using African monkey kidney epithelial (Vero) cells. All 24 extracts from the four medicinal plants showed inhibitory activity against all fungal species, except Aspergillus fumigatus, with a minimum inhibitory concentration range of $0.04-2.50 \mathrm{mg} / \mathrm{mL}$. The antifungal activity of these plants was more prominent on the yeasts than the filamentous fungi. Generally, the less polar extracts (hexane, chloroform, and ethyl acetate) of the plants had stronger antifungal activity than the more polar extracts (ethanol, methanol, and water). In contrast, toxicity assessment revealed that the less polar extracts showed relatively higher toxicity towards the Vero cells than the more polar extracts. The lowest median cytotoxic concentration was shown by the chloroform extract of $A$. sessilis $(17.4 \pm 0.4 \mu \mathrm{g} / \mathrm{mL})$. All water extracts, the methanol extract of $I$. aquatica, and the ethyl acetate, ethanol, and methanol extracts of $T$. spathacea did not show significant toxicity $(P>0.05)$ towards the Vero cells. The results suggested that Tradescantia spathacea has the most promising potential for pharmaceutical developments due to its broad spectrum and selective activity against human fungal pathogens.
\end{abstract}

Keywords: Antifungal; Alternanthera sessilis; Catunaregam spinosa; Ipomoea aquatica; Tradescantia spathacea.

\section{INTRODUCTION}

Infectious diseases remain a major leading cause of morbidity and mortality worldwide. A wide spectrum of infections is produced by pathogenic fungi, ranging from superficial, mucosal, allergic, chronic severe, to invasive infections (Bongomin et al., 2017). People living with human immunodeficiency virus, transplant recipients, patients with cancer, patients receiving immunomodulators, premature neonates, and the elderly are more vulnerable to fungal infections (Vallabhaneni et al., 2016). In 2017, the global incidence of fungal skin infections such as dermatophytosis or tinea, superficial candidiasis, and Malassezia infections was recorded more than 2.1 billion cases (GBD 2017 Disease and Injury Incidence and Prevalence Collaborators, 2018). Although invasive fungal infections have a lower incidence than fungal skin infections, they are often associated with high fatality rates, i.e., $46-75 \%, 20-70 \%$, and $30-95 \%$ for invasive candidiasis, cryptococcosis, and aspergillosis, respectively
(Brown et al., 2012). Effective antifungal therapy is thus essential to reduce the mortality of fungal diseases. However, the successful outcome of antifungal therapy is hampered by the development of drug resistance, side effects or adverse effects of antifungal drugs, and undesirable drugdrug interactions (Nett \& Andes, 2016; Perlin et al., 2017).

In view of these limitations, there is a clear demand for newer and safer antifungal drugs. Plants are a promising source of antimicrobial substances due to their abundant primary and secondary metabolites with vast chemical diversity. These bioactive metabolites can be broadly divided into four groups, i.e., alkaloids, terpenes, phenolics, and peptides (Singh, 2017). Owing to their physicochemical properties, solvents of low polarity such as hexane, chloroform, or ethyl acetate are used to extract alkaloids and terpenes while solvents of high polarity such as ethanol, methanol, or water can yield phenolics and peptides from the plants for bioactivity evaluations (Cowan, 1999). 
Alternanthera sessilis (L.) R.Br. ex DC. (Amaranthaceae) is an annual or perennial prostrate herb with several spreading branches, simple, lanceolate or linear-oblong leaves, and small white flowers. It is commonly known as sessile joyweed or dwarf copperleaf (Thomas et al., 2014). Catunaregam spinosa (Thunb.) Tirveng. (Rubiaceae), commonly called mountain pomegranate, is a perennial, large thorny shrub that is found in moist deciduous forests. The synonyms are Randia dumetorum and $R$. spinosa. The leaves are simple, obovate, wrinkled, shiny, and pubescent (Patel et al., 2011). Ipomoea aquatica Forssk. (Convolvulaceae) is a tender, trailing perennial aquatic plant that thrives on moist soil along the margins of freshwater and in ditches, marshes, and paddy fields. It is commonly known as water spinach or water convolvulus and is cultivated as a green leafy vegetable in Malaysia, Singapore, Indonesia, Hong Kong, Taiwan, and China (Manvar \& Desai, 2013). Tradescantia spathacea Sw. (syn. Rhoeo discolor or $R$. spathacea) is a weakly upright, $30-60 \mathrm{~cm}$ tall plant belonging to the family Commelinaceae. The leaves are large, imbricated, green above, and purple beneath (Parivuguna et al., 2008). It has many common names such as maguey, purple maguey, oyster plant, boat lily, Moses in a basket, and Moses-in-the-Cradle.

The selected medicinal plants have been scientifically and extensively studied against human pathogenic bacteria (Egami et al., 1998; Parivuguna et al., 2008; Shailasree et al., 2014; Sivagurunathan et al., 2015; Tan et al., 2015; Kota et al., 2017) or viruses such as herpes simplex virus type 1 for A. sessilis (Taylor et al., 1996) and Chikungunya virus for I. aquatica and T. spathacea (Chan et al., 2016). However, there is scarce information about the plants against fungal pathogens. This study was thus performed to evaluate the aerial parts of $A$. sessilis and I. aquatica, and the leaves of C. spinosa and $T$. spathacea for inhibitory and fungicidal activities against human fungal pathogens. The toxicity of the plant extracts, obtained by sequential solvent extraction, was assessed using a normal mammalian cell line, which is African monkey kidney epithelial (Vero) cells.

\section{MATERIALS AND METHODS}

\section{Plant samples}

The aerial parts of Alternanthera sessilis and Ipomoea aquatica were obtained from a herbal garden and a wet market, respectively in Kampar, Perak. The leaves of Catunaregam spinosa were collected from a farm in Chemor, Perak while the leaves of Tradescantia spathacea were harvested from a garden in Batu Pahat, Johor. All plant species were identified by Dr. Hean Chooi Ong, a former ethnobotany professor from the University of Malaya, Malaysia, and their scientific names were cross-checked using the World Flora Online database (World Flora Online Consortium, 2020). Specimen vouchers of the plants were prepared and deposited at the Faculty of Science, Universiti Tunku Abdul Rahman, Malaysia. The vouchers were labeled as UTAR/FSC/13/009 for $A$. sessilis, UTAR/FSC/13/003 for C. spinosa, UTAR/FSC/13/010 for I. aquatica, and UTAR/FSC/13/006 for T. spathacea.

\section{Preparation of plant extracts}

The fresh plant materials were rinsed with tap water, then cut and blended into fine pieces before extraction. The aerial parts or leaves were macerated sequentially using hexane, chloroform, ethyl acetate, ethanol, methanol, and distilled water. The maceration was performed at room temperature with agitation (150 rpm) for two cycles (one day/cycle). The filtrates from each cycle were pooled and the organic solvents and water were removed using rotary-evaporation at $40^{\circ} \mathrm{C}$ and Iyophilization, respectively. The dry extracts obtained were stored at $-20^{\circ} \mathrm{C}$ prior to analysis.

\section{Antifungal assay}

All plant extracts were evaluated for antifungal activity using a colorimetric broth microdilution method, as described previously (Sit et al., 2017). Briefly, six fungal species, consisting of four yeasts (Candida albicans ATCC $90028^{\text {TM }}$, Candida parapsilosis ATCC $^{\circ} 22019^{\text {TM }}$, Candida krusei ATCC $^{\oplus} 6258^{\text {tm }}$ (teleomorph), and Cryptococcus neoformans ATCC ${ }^{\circ} 90112^{\text {TM }}$ ) and two filamentous fungi (Aspergillus fumigatus ATCC $^{\circ} 204305^{\mathrm{TM}}$ and Trichophyton interdigitale ATCC $9533^{\mathrm{T}}$ ) , were used. Each plant extract was serially diluted in a methanol-water mixture $(2: 1, v / v)$ to produce eight different concentrations $(0.02,0.04$, $0.08,0.16,0.31,0.63,1.25$, and $2.50 \mathrm{mg} / \mathrm{mL}$ ) for the assay. The antibiotic amphotericin B $(0.06-8 \mu \mathrm{g} / \mathrm{mL})$ was used as a positive control. Blank medium (Roswell Park Memorial Institute 1640 medium), fungus without the addition of extract, and extract without the addition of fungal inoculum were included in each 96 -well microplate as controls. The microplates were incubated at $35^{\circ} \mathrm{C}$ for $48 \mathrm{~h}$ for the Candida spp.; $35^{\circ} \mathrm{C}$ for $72 \mathrm{~h}$ for $\mathrm{C}$. neoformans and A. fumigatus, and $28^{\circ} \mathrm{C}$ for 7 days for $T$. interdigitale. After appropriate incubations, $20 \mu \mathrm{L}$ of $0.4 \mathrm{mg} / \mathrm{mL}$ iodonitrotetrazolium chloride was added into each well of the microplate, and the formation of colored precipitate was observed. Minimum inhibitory concentration (MIC) was recorded as the lowest extract concentration in which no colored precipitate was formed in the well. Subsequently, $20 \mu \mathrm{L}$ of the content from the wells with no precipitate formed was taken and swabbed on Sabouraud dextrose agar (for yeasts) or potato dextrose agar (for filamentous fungi). The lowest concentration of the extract which kills the fungus, designated as minimum fungicidal concentration (MFC), was determined after incubation. The experiment was carried out in triplicate.

\section{Toxicity assay}

A normal mammalian cell line, African monkey kidney epithelial (Vero) cells (ATCC ${ }^{\circ} \mathrm{CCL}-81^{\mathrm{TM}}$ ) was deployed to assess the toxicity of the extracts (Chan et al., 2015). The cells were maintained in Dulbecco's modified Eagle's medium (DMEM) at $37^{\circ} \mathrm{C}$ in a humidified atmosphere with $5 \% \mathrm{CO}_{2}$. A 96-well, flat-bottom microplate was seeded with 40,000 cells/well and incubated for $24 \mathrm{~h}$ at $37^{\circ} \mathrm{C}$ and $5 \% \mathrm{CO}_{2}$. After that, $100 \mu \mathrm{L}$ of extract at different concentrations $(5,10,20,40,80,160,320$, and $640 \mu \mathrm{g} / \mathrm{mL}$ ) was added into the test wells. Vero cellcontaining wells and DMEM-containing wells (without any extract) in each microplate served as cell control and medium control, respectively. The microplate was further incubated for $72 \mathrm{~h}$ at $37^{\circ} \mathrm{C}$ and $5 \% \mathrm{CO}_{2}$. The cell viability was then determined using the neutral red uptake assay. The median cytotoxic concentration $\left(\mathrm{CC}_{50}\right)$ was interpolated from the plot of percentage of cell viability against concentration of extract. The toxicity assessment was performed in three independent experiments with duplication in each experiment.

\section{Data analysis}

Fungal susceptibility index is calculated using the following formula and expressed in percentage.

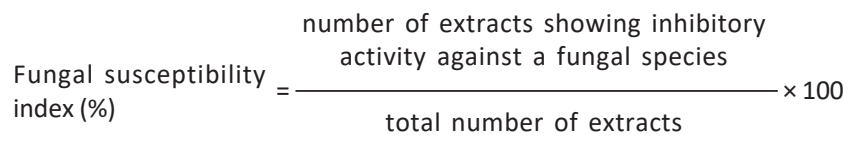

The data from the toxicity assessment was subjected to significance testing by independent-samples T-test or oneway analysis of variance (ANOVA), followed by the post hoc 
test, either with Tukey's or Dunnett's test. The significance level was set at $P<0.05$. The statistical analysis was performed using the IBM SPSS Statistics for Windows Version 23 software.

\section{RESULTS AND DISCUSSION}

A colorimetric broth microdilution method was used to examine the antifungal activities of plant extracts against six species of fungi. The fungal species chosen are common pathogens causing dermatophytosis (Trichophyton interdigitale), superficial or invasive candidiasis (Candida albicans, C. parapsilosis, and C. krusei), cryptococcosis (Cryptococcus neoformans), and aspergillosis (Aspergillus fumigatus) in humans. Amphotericin B, which is a broadspectrum antifungal drug, was used as the positive control for all the fungal pathogens in the study. Although the dermatophyte $T$. interdigitale is usually treated using terbinafine, griseofulvin, or itraconazole (Durdu et al., 2017), it is susceptible to amphotericin B in vitro (Altınbaş et al., 2018; Singh et al., 2019).

As shown in Table 1, all 24 extracts from the four medicinal plants showed different degrees of antifungal activity on all the fungal species evaluated, except $A$. fumigatus. The extracts displayed more inhibitory activities than fungicidal effects. By considering one extract against one fungal species as one bioassay, $62.5 \%(90 / 144)$ of the bioassays showed inhibitory activity while only $41.7 \%(60 / 144)$ of them showed fungicidal activity. The MIC and MFC values of the extracts were in the range of $0.04-2.50$ and $0.08-2.50 \mathrm{mg} / \mathrm{mL}$, respectively.

The results also showed that yeasts were more susceptible to the antifungal effects of plant extracts than filamentous fungi. The fungal susceptibility indices for C. albicans, C. parapsilosis, C. krusei, and C. neoformans were $79.2 \%, 87.5 \%, 62.5 \%$, and $100 \%$, respectively while the fungal susceptibility index for $T$. interdigitale was only $45.8 \%$. Furthermore, none of the extracts were able to inhibit the growth of $A$. fumigatus. This implies that the morphological structures of unicellular yeasts are more vulnerable to the antifungal actions of phytochemicals than the multicellular hyphae of filamentous fungi. Such resistivity of filamentous fungi towards plant extracts has been reported by other studies (Kurdekar et al., 2012; Rawat et al., 2016; Ong et al., 2020).

In this study, phytochemicals were extracted from the medicinal plants using solvents of increasing polarity, ranging from the most non-polar solvent hexane, chloroform, ethyl acetate, ethanol, methanol, to the most polar solvent water. In general, as the polarity of an extractant increased, the inhibitory activity of an extract against fungi decreased, as evident from the increasing MIC values across the extracts (Table 1). Notably, the ethanol, methanol, and water extracts of $C$. spinosa were only active against $C$. neoformans (Table 1 ). Using the classification proposed by Saraiva et al. (2011), the hexane extracts of all plants, the chloroform and ethyl acetate extracts of $C$. spinosa, and the chloroform extract of $T$. spathacea

Table 1. Minimum inhibitory concentrations and minimum fungicidal concentrations of medicinal plant extracts against human fungal pathogens

\begin{tabular}{|c|c|c|c|c|c|c|c|c|c|c|c|c|}
\hline & \multicolumn{6}{|c|}{ Minimum inhibitory concentration $(\mathrm{mg} / \mathrm{mL})$} & \multicolumn{6}{|c|}{ Minimum fungicidal concentration $(\mathrm{mg} / \mathrm{mL})$} \\
\hline & CA & $C P$ & CK & $\mathrm{CN}$ & $\mathrm{AF}$ & $\mathrm{TI}$ & CA & $\mathrm{CP}$ & CK & $\mathrm{CN}$ & AF & $\mathrm{TI}$ \\
\hline \multicolumn{13}{|c|}{ Alternanthera sessilis } \\
\hline Hexane & 1.25 & 0.31 & 0.08 & 0.04 & $>2.50$ & 0.31 & $>2.50$ & 0.63 & 0.08 & 0.08 & - & 0.63 \\
\hline Chloroform & 0.31 & 0.63 & 0.63 & 0.16 & $>2.50$ & 1.25 & $>2.50$ & 1.25 & 0.63 & 0.31 & - & 2.50 \\
\hline Ethyl acetate & 0.63 & 0.63 & 0.63 & 0.16 & $>2.50$ & 1.25 & $>2.50$ & $>2.50$ & 1.25 & 0.31 & - & 2.50 \\
\hline Ethanol & 2.50 & 1.25 & $>2.50$ & 0.16 & $>2.50$ & 2.50 & 2.50 & 2.50 & - & 1.25 & - & $>2.50$ \\
\hline Methanol & 2.50 & 1.25 & 2.50 & 0.16 & $>2.50$ & $>2.50$ & $>2.50$ & 1.25 & $>2.50$ & 2.50 & - & - \\
\hline Water & $>2.50$ & 1.25 & $>2.50$ & 0.08 & $>2.50$ & $>2.50$ & - & 1.25 & - & 0.63 & - & - \\
\hline \multicolumn{13}{|c|}{ Catunaregam spinosa } \\
\hline Hexane & 0.31 & 0.31 & 0.31 & 0.04 & $>2.50$ & 0.31 & 0.31 & 0.63 & 0.31 & 0.08 & - & 0.63 \\
\hline Chloroform & 0.31 & 0.31 & 0.31 & 0.04 & $>2.50$ & 0.31 & 0.31 & 0.63 & 0.31 & 0.08 & - & 0.63 \\
\hline Ethyl acetate & 1.25 & 1.25 & 1.25 & 0.08 & $>2.50$ & 1.25 & 1.25 & $>2.50$ & 1.25 & 0.16 & - & 2.50 \\
\hline Ethanol & $>2.50$ & $>2.50$ & $>2.50$ & 0.16 & $>2.50$ & $>2.50$ & - & - & - & $>2.50$ & - & - \\
\hline Methanol & $>2.50$ & $>2.50$ & $>2.50$ & 0.16 & $>2.50$ & $>2.50$ & - & - & - & $>2.50$ & - & - \\
\hline Water & $>2.50$ & $>2.50$ & $>2.50$ & 0.16 & $>2.50$ & $>2.50$ & - & - & - & $>2.50$ & - & - \\
\hline \multicolumn{13}{|c|}{ Ipomoea aquatica } \\
\hline Hexane & 0.16 & 0.31 & 0.31 & 0.08 & $>2.50$ & 0.31 & 0.16 & 0.31 & 0.31 & 0.08 & - & 0.31 \\
\hline Chloroform & 0.63 & 0.63 & 1.25 & 0.16 & $>2.50$ & 0.63 & $>2.50$ & 1.25 & 1.25 & 0.31 & - & 1.25 \\
\hline Ethyl acetate & 1.25 & 0.63 & $>2.50$ & 0.16 & $>2.50$ & $>2.50$ & $>2.50$ & 1.25 & - & $>2.50$ & - & - \\
\hline Ethanol & 1.25 & 0.63 & $>2.50$ & 0.16 & $>2.50$ & $>2.50$ & $>2.50$ & 1.25 & - & $>2.50$ & - & - \\
\hline Methanol & 2.50 & 0.63 & $>2.50$ & 0.16 & $>2.50$ & $>2.50$ & $>2.50$ & 1.25 & - & $>2.50$ & - & - \\
\hline Water & $>2.50$ & 0.63 & $>2.50$ & 0.16 & $>2.50$ & $>2.50$ & - & 1.25 & - & $>2.50$ & - & - \\
\hline \multicolumn{13}{|c|}{ Tradescantia spathacea } \\
\hline Hexane & 0.31 & 0.31 & 0.63 & 0.08 & $>2.50$ & 0.31 & 0.31 & 0.31 & 0.63 & 0.08 & - & 0.63 \\
\hline Chloroform & 0.31 & 0.31 & 0.63 & 0.08 & $>2.50$ & 0.63 & 0.31 & 0.63 & 0.63 & 0.16 & - & 1.25 \\
\hline Ethyl acetate & 0.63 & 0.63 & 0.63 & 0.31 & $>2.50$ & $>2.50$ & $>2.50$ & $>2.50$ & $>2.50$ & $>2.50$ & - & - \\
\hline Ethanol & 0.63 & 0.63 & 0.63 & 0.16 & $>2.50$ & $>2.50$ & $>2.50$ & $>2.50$ & 0.63 & $>2.50$ & - & - \\
\hline Methanol & 0.63 & 0.63 & 0.63 & 0.16 & $>2.50$ & $>2.50$ & 0.63 & 1.25 & 0.63 & $>2.50$ & - & - \\
\hline Water & 0.63 & 0.63 & 0.63 & 0.31 & $>2.50$ & $>2.50$ & $>2.50$ & $>2.50$ & 0.63 & $>2.50$ & - & - \\
\hline Amphotericin B & 1 & $0.5-1$ & $1-2$ & 0.13 & 4 & $2-4$ & - & - & - & - & - & - \\
\hline
\end{tabular}

The concentrations are expressed as means of three consistent replicates. The concentration of amphotericin B is expressed as $\mu \mathrm{g} / \mathrm{mL}$. ' - ': no tested; CA: Candida albicans; CP: Candida parapsilosis; CK: Candida krusei; CN: Cryptococcus neoformans; AF: Aspergillus fumigatus; TI: Trichophyton interdigitale. 
were regarded as highly active extracts, especially against $C$. neoformans, as their MIC values were lower than $0.1 \mathrm{mg} / \mathrm{mL}$.

To the best of our knowledge, this study is the first report of antifungal activities of the leaves of $C$. spinosa. Very little is known about the phytochemicals in the leaves of this plant. An iridoid known as 10-methylixoside was isolated from the leaves of $C$. spinosa (Sati et al., 1986) but its antimicrobial activity remains to be explored. The results of A. sessilis from the present study are in agreement with the study by $D$ et al. (2014) who reported the inhibitory activities of the ethanol extract derived from the leaves against several fungal species, including $C$. albicans with a MIC value of 0.2 $\mathrm{mg} / \mathrm{mL}$. However, no fungicidal evaluation was attempted in the study. An ionone derivative with a weak antifungal activity against $T$. interdigitale (formerly known as Trichophyton mentagrophytes) was isolated from the chloroform extract of the air-dried leaves of $A$. sessilis (Ragasa et al., 2002). Our results suggested that different phytochemicals were responsible for the antifungal activities of $A$. sessilis as many classes of secondary metabolites, i.e., alkaloids, flavonoids, cardiac glycosides, saponins, sterols, and terpenoids are found in the leaves or shoots of $A$. sessilis (Kota et al., 2017; Manalo et al., 2020).

The antifungal activities of the leaf extracts of $T$. spathacea were corroborated with the findings reported by García-Varela et al. (2015) using agar diffusion assays, in which C. albicans was the only fungal species used in the study. Alkaloids, cardiac glycosides, flavonoids, saponins, steroids, tannins, and terpenoids have been reported from the leaves of $T$. spathacea (Parivuguna et al., 2008; Radji et al., 2015) and they are likely to account for the antifungal activities observed in this study. Choudhury et al. (2007) studied the antifungal activity of the twigs and leaves of $I$. aquatica against $C$. albicans using a broth macrodilution method. The MIC value for the methanol extract, obtained by direct solvent extraction, was $0.25 \mathrm{mg} / \mathrm{mL}$, a value which is 10 -fold lower than our results (Table 1). Different extraction techniques such as direct and sequential extractions will result in different phytochemical compositions in an extract (Maria John et al., 2018), and thus affect the biological activities of the extract. Several flavonoids (quercetin, quercetin 3 '-methylether, quercetin 4 '-methylether, and $3 \alpha-7 \beta-0-D$-diglycopyranosyldihydroquercetin), anthocyanins, and carotenoids are present in the aerial parts of I. aquatica (Meira et al., 2012; Malakar \& Choudhury, 2015). Notably, quercetin possesses inhibitory activity against C. parapsilosis (Rocha et al., 2019) and C. neoformans (Oliveira et al., 2016) but is inactive against C. albicans and C. krusei (Geoghegan et al., 2010). Nevertheless, the present study indicated that the aerial parts of $I$. aquatica and the leaves of $T$. spathacea possessed broad-spectrum antifungal activity.

Vero cells are one of the most common continuous mammalian cell lines used for various applications such as propagation of intracellular bacteria or viruses, detection of toxins, production of vaccines, and toxicity assessment of chemicals or plant extracts (Ammerman et al., 2008). The toxicity assessment revealed that the less polar plant extracts, i.e., hexane, chloroform, and ethyl acetate were relatively more toxic to the Vero cells compared to the more polar ethanol and methanol extracts (Figure 1). These toxicities were also reflected by their median cytotoxic concentrations $\left(\mathrm{CC}_{50}\right)$ as shown in Table 2 . The lowest $\mathrm{CC}_{50}$ value, $17.4 \pm 0.4 \mu \mathrm{g} / \mathrm{mL}$, was exhibited by the chloroform extract of $A$. sessilis. On the other hand, all water extracts did not show significant toxicity $(P>0.05)$ towards the cells at the concentration range $(5-640 \mu \mathrm{g} / \mathrm{mL})$ evaluated. Shailasree et al. (2014) evaluated the cytotoxicity of the methanol extract of the leaves of $C$. spinosa on Vero cells using the MTT assay and reported an $\mathrm{IC}_{50}$ (or $\mathrm{CC}_{50}$ ) value of $127.6 \mu \mathrm{g} / \mathrm{mL}$. The present study reported a much higher $\mathrm{CC}_{50}$ value $(374.9 \mu \mathrm{g} / \mathrm{mL})$ for the methanol extract. The difference could be due to agrogeographical reasons or extraction techniques (direct vs sequential) used. Tasiam et al. (2020) reported that the ethyl acetate fraction of the leaves of Cassia siamea collected from Pariaman (West Sumatera) showed significantly higher cytotoxicity against human liver cancer cell line (Huh7it) than the ones collected from Palu (Central Sulawesi) and Surabaya (East Java). Fong et al. (2016) studied the methanol extracts of the leaves of Clinacanthus nutans collected from Malaysia, Thailand, and Vietnam. They noticed that the plants grown at higher temperatures and lower elevations had weaker cytotoxic activity toward D24 human melanoma cells than those grown at lower temperatures and higher elevations. Maria John et al. (2018) compared the phytochemicals in the black bean and soybean using sequential solvent extraction and direct solvent extraction and found that 18 metabolites of black bean and 11 metabolites of soybean varied significantly between the two techniques. Besides, cell viability indicators such as MTT and neutral red have been recognized as a contributor to the differences in toxicity results involving plant extracts (Chan et al., 2015). It is suggested that further toxicity evaluation can be performed using human keratinocytes or vaginal epithelial cells if the bioactive compounds from the extracts are to be used topically or as a suppository.

It is interesting to note that the ethyl acetate, ethanol, methanol, and water extracts of $T$. spathacea were not toxic $(P>0.05)$ towards the Vero cells (Figure 1$)$. Unlike the water extracts of the other three medicinal plants with limited antifungal activities, these non-toxic extracts of $T$. spathacea were also active against the fungi, especially the four species of yeasts. As plant extract is a mixture of phytochemicals, this suggests that the extracts of $T$. spathacea are potential sources of antifungal compounds, likely with different physicochemical properties, and their activities are more selective towards human fungal pathogens.

\section{CONCLUSION}

The results of the present study highlighted that the aerial parts of $A$. sessilis and I. aquatica, and the leaves of $C$. spinosa and $T$. spathacea possess antifungal activity against human fungal pathogens. The antifungal activity and the cytotoxicity of the plant extracts depended on the concentrations used in the assay and the type of solvents used in the extraction. The antifungal activity of the plant extracts was also relied on the fungal species evaluated. Among the medicinal plants, T. spathacea has the most promising potential for pharmaceutical developments due to its broad spectrum and selective activity against the fungal species. This warrants further work to isolate and identify the antifungal principles from the bioactive extracts and investigate their mechanisms of action.

\section{ACKNOWLEDGEMENTS}

The authors thank Universiti Tunku Abdul Rahman for financial support and Ms. Yik Sin Chan for the technical assistance on cytotoxicity assay.

\section{Conflict of interest}

The authors declare that they have no conflict of interest. 

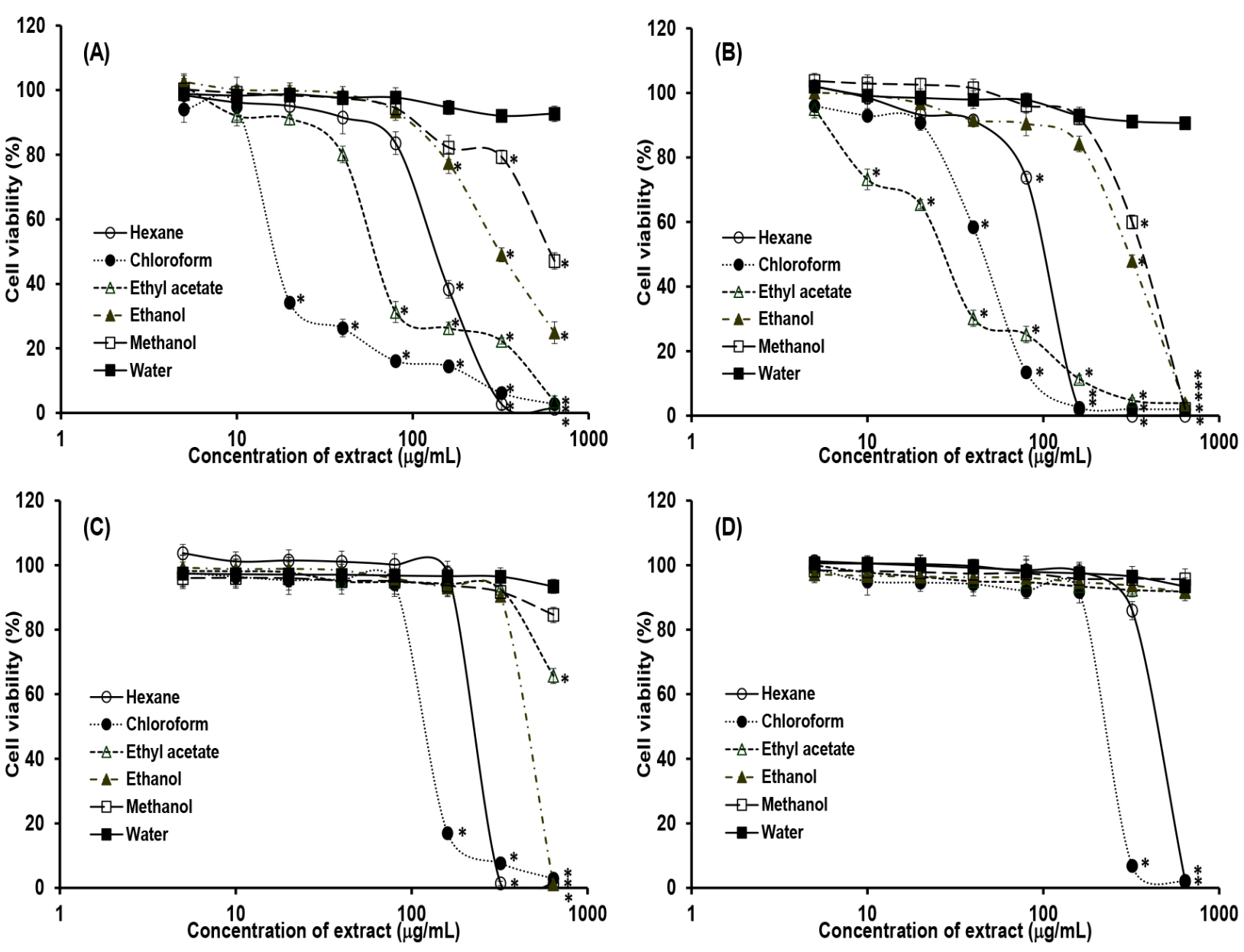

Figure 1. Viability of African monkey kidney epithelial (Vero) cells treated with various extracts obtained from the medicinal plants Alternanthera sessilis (A), Catunaregam spinosa (B), Ipomoea aquatica (C), and Tradescantia spathacea (D). Each data point is expressed as mean \pm standard deviation of three replicates. The notated asterisks denote significant differences by one-way ANOVA $(P<0.05)$. The $x$-axis is presented on a log scale.

Table 2. Median cytotoxic concentrations of medicinal plant extracts evaluated using African monkey kidney epithelial (Vero) cells

\begin{tabular}{lcccc}
\hline \multirow{2}{*}{ Plant extract } & \multicolumn{4}{c}{ Median cytotoxic concentrations, $\mathrm{CC}_{50}(\mathrm{\mu g} / \mathrm{mL})$} \\
\cline { 2 - 5 } & Alternanthera sessilis & Catunaregam spinosa & Ipomoea aquatica & Tradescantia spathacea \\
\hline Hexane & $139.5 \pm 4.2^{\mathrm{c}}$ & $106.5 \pm 0.7^{\mathrm{c}}$ & $239.1 \pm 3.4^{\mathrm{b}}$ & $457.2 \pm 6.2^{\mathrm{a}}$ \\
Chloroform & $17.4 \pm 0.4^{\mathrm{a}}$ & $47.4 \pm 1.3^{\mathrm{b}}$ & $125.7 \pm 2.1^{\mathrm{a}}$ & $238.5 \pm 3.1^{\mathrm{b}}$ \\
Ethyl acetate & $64.7 \pm 1.3^{\mathrm{b}}$ & $28.8 \pm 0.6^{\mathrm{a}}$ & $>640$ & - \\
Ethanol & $315.4 \pm 12.1^{\mathrm{d}}$ & $311.2 \pm 7.8^{\mathrm{d}}$ & $464.9 \pm 2.8^{\mathrm{c}}$ & - \\
Methanol & $613.0 \pm 22.0^{\mathrm{e}}$ & $374.9 \pm 9.8^{\mathrm{e}}$ & - & - \\
Water & - & - & - & - \\
\hline
\end{tabular}

The values are expressed as means \pm standard deviations of triplicates. ' - ' denotes no siginifcant cytotoxicity even at the highest concentration tested $(640 \mu \mathrm{g} / \mathrm{mL})$. Mean values with different superscript letters $(a, b, c, d$, e) denote the extracts are significantly different $(P<0.05)$ from each other by one-way ANOVA or independent-samples T-test.

\section{REFERENCES}

Ammerman, N.C., Beier-Sexton, M. \& Azad, A.F. (2008). Growth and maintenance of Vero cell lines. Current Protocols in Microbiology 11: A.4E.1-A.4E.7. https://doi.org/10.1002/ 9780471729259.mca04es11

Altınbaş, R., Özakkaş, F., Barış, A., Turan, D. \& Şen, S. (2018). In vitro susceptibility of seven antifungal agents against dermatophytes isolated in Istanbul. Turkish Journal of Medical Sciences 48: 615-619. https://doi.org/10.3906/sag1709-157.
Bongomin, F., Gago, S., Oladele, R.O. \& Denning, D.W. (2017). Global and multi-national prevalence of fungal diseasesestimate precision. Journal of Fungi 3: 57. https://doi.org/ 10.3390/jof3040057

Brown, G.D., Denning, D.W., Gow, N.A., Levitz, S.M., Netea, M.G. \& White, T.C. (2012). Hidden killers: human fungal infections. Science Translational Medicine 4: 165rv13. https://doi.org/10.1126/scitranslmed.3004404

Chan, S.M., Khoo, K.S. \& Sit, N.W. (2015). Interactions between plant extracts and cell viability indicators during cytotoxicity testing: implications for ethnopharmacological 
studies. Tropical Journal of Pharmaceutical Research 14: 19911998. https://doi.org/10.4314/tjpr.v14i11.6

Chan, Y.S., Khoo, K.S. \& Sit, N.W. (2016). Investigation of twenty selected medicinal plants from Malaysia for antiChikungunya virus activity. International Microbiology 19: 175-182. https://doi.org/10.2436/20.1501.01.275

Choudhury, M.D., Choudhury, R., De, B. \& Paul, S.B. (2007). Physicochemical characterisation and antifungal, CNS depressant activity of certain ethnomedicinal plants of Tripura state, India. Biosciences Biotechnology Research Asia 4: 145-148.

Cowan, M.M. (1999). Plant products as antimicrobial agents. Clinical Microbiology Reviews 12: 564-582. https://doi.org/ 10.1128/CMR.12.4.564

D, A.K., Das, M., Mohanraj, P. \& Das, A. (2014). Antimicrobial activity study of ethanolic extract of Alternanthera sessilis Linn. aerial parts. Journal of Applied Pharmaceutical Research 2: 1-4.

Durdu, M., Ilkit, M., Tamadon, Y., Tolooe, A., Rafati, H. \& Seyedmousavi, S. (2017). Topical and systemic antifungals in dermatology practice. Expert Review of Clinical Pharmacology 10: 225-237. https://doi.org/10.1080/17512433.2017. 1263564

Egami, E.L., Magboul, A.L., Omer, M.E. \& Tohami, E.L. (1998). Sudanese plant used in folkloric medicine: screening for antibacterial activity. Fitoterapia 59: 369-373. https://doi. org/10.1016/s0367-326x(01)00310-0

Fong, S.Y., Piva, T., Dekiwadia, C., Urban, S. \& Huynh, T. (2016). Comparison of cytotoxicity between extracts of Clinacanthus nutans (Burm. f.) Lindau leaves from different locations and the induction of apoptosis by the crude methanol leaf extract in D24 human melanoma cells. BMC Complementary and Alternative Medicine 16: 368. https://doi.org/ 10.1186/s12906-016-1348-x

García-Varela, R., García-García, R.M., Barba-Dávila, B.A., Fajardo-Ramírez, O.R., Serna-Saldívar, S.O. \& Cardineau, G.A. (2015). Antimicrobial activity of Rhoeo discolor phenolic rich extracts determined by flow cytometry. Molecules 20: 18685-18703. https://doi.org/10.3390/molecules201018685

GBD 2017 Disease and Injury Incidence and Prevalence Collaborators. (2018). Global, regional, and national incidence, prevalence, and years lived with disability for 354 diseases and injuries for 195 countries and territories, 1990-2017: a systematic analysis for the global burden of disease study 2017. Lancet 392: 1789-1858. https://doi.org/10.1016/S0140-6736(18)32279-7

Geoghegan, F., Wong, R.W.K. \& Rabie, A.B.M. (2010). Inhibitory effect of quercetin on periodontal pathogens in vitro. Phytotherapy Research 24: 817-820. https://doi.org/10.1002/ ptr.3014

Kota, S., Govada, V.R., Anantha, R.K. \& Verma, M.K. (2017). An investigation into phytochemical constituents, antioxidant, antibacterial and anti-cataract activity of Alternanthera sessilis, a predominant wild leafy vegetable of South India. Biocatalysis and Agricultural Biotechnology 10: 197-203. https://doi.org/10.1016/j.bcab.2017.03.008

Kurdekar, R.R., Hegde, G.R., Hegde, G. \& Hebbar, S.S. (2012). Antimicrobial screening of medicinal plants against human pathogens - a comparative account of two different methods of extraction. International Journal of Drug Development and Research 4: 82-89.

Malakar, C. \& Choudhury, P.P.N. (2015). Pharmacological potentiality and medicinal uses of Ipomoea aquatica Forsk: a review. Asian Journal of Pharmaceutical and Clinical Research 8: $60-63$.
Manalo, R.A.M., Arollado, E.C. \& Heralde, F.M. (2020). Alternanthera sessilis leaf fractions possess in vitro inhibitory activities in mammalian $\alpha$-amylase and $\alpha$ glucosidase. Pharmaceutical Sciences Asia 47: 279-286. https://doi.org/10.29090/psa.2020.03.019.0076

Manvar, M.N. \& Desai, T.R. (2013). Phytochemical and pharmacological profile of Ipomoea aquatica. Indian Journal of Medical Sciences 67: 49-60. https://doi.org/10.4103/00195359.121115

Maria John, K.M., Harnly, J. \& Luthria, D. (2018). Influence of direct and sequential extraction methodology on metabolic profiling. Journal of Chromatography B 1073: 3442. https://doi.org/10.1016/j.jchromb.2017.12.005

Meira, M., da Silva, E.P., David, J.M. \& David, J.P. (2012). Review of the genus Ipomoea: Traditional uses, chemistry and biological activities. Revista Brasileira de Farmacognosia 22: 682-713. https://doi.org/10.1590/S0102-695X201200 5000025

Nett, J.E. \& Andes, D.R. (2016). Antifungal agents: spectrum of activity, pharmacology, and clinical indications. Infectious Disease Clinics of North America 30: 51-83. https://doi.org/ 10.1016/j.idc.2015.10.012

Oliveira, V.M., Carraro, E., Auler, M.E. \& Khalil, N.M. (2016). Quercetin and rutin as potential agents antifungal against Cryptococcus spp. Brazilian Journal of Biology 76: 10291034. https://doi.org/10.1590/1519-6984.07415

Ong, C.W., Chan, Y.S., Chan, S.M., Chan, M.W., Teh, E.L., Soh, C.L.D., Khoo, K.S., Ong, H.C. \& Sit, N.W. (2020). Antifungal, antibacterial and cytotoxic activities of non-indigenous medicinal plants naturalised in Malaysia. Farmacia 68: 687-696. https://doi.org/10.31925/farmacia.2020.4.14

Parivuguna, V., Ganaprabhal, R., Dhanabalan, R. \& Doss, A. (2008). Antimicrobial properties and phytochemical constituents of Rhoeo discolor Hance. Ethnobotanical Leaflets 12: 841-845.

Patel, R.G., Pathak, N.L., Rathod, J.D., Patel, L.D. \& Bhatt, N.M. (2011). Phytopharmacological properties of Randia dumetorum as a potential medicinal tree: an overview. Journal of Applied Pharmaceutical Science 1: 24-26.

Perlin, D.S., Rautemaa-Richardson, R. \& Alastruey-Izquierdo, A. (2017). The global problem of antifungal resistance: prevalence, mechanisms, and management. The Lancet Infectious Diseases 17: e383-e392. https://doi.org/10.1016/ S1473-3099(17)30316-X

Radji, M., Kurniati, M. \& Kiranasari, A. (2015). Comparative antimycobacterial activity of some Indonesian medicinal plants against multi-drug resistant Mycobacterium tuberculosis. Journal of Applied Pharmaceutical Science 5: 019022. https://doi.org/10.7324/JAPS.2015.50104

Ragasa, C.Y., Tremor, N. \& Rideout, J.A. (2002). Ionone derivatives from Alternanthera sessilis. Journal of Asian Natural Products Research 4: 109-115. https://doi.org/10.1080/10286020 290027380

Rawat, S., Jugran, A.K., Bahukhandi, A., Bahuguna, A., Bhatt, I.D., Rawal, R.S. \& Dhar, U. (2016). Anti-oxidant and antimicrobial properties of some ethno-therapeutically important medicinal plants of Indian Himalayan region. 3 Biotech 6: 154. https://doi.org/10.1007/s13205-016-0470-2

Rocha, M.F.G., Sales, J.A., da Rocha, M.G., Galdino, L.M., de Aguiar, L., Pereira-Neto, W.D.A., de Agular Cordeiro, R., Castelo-Branco, D.D.S.C.M., Sidrim, J.J.C. \& Brilhante, R.S.N. (2019). Antifungal effects of the flavonoids kaempferol and quercetin: a possible alternative for the control of fungal biofilms. Biofouling 35: 320-328. https://doi.org/ 10.1080/08927014.2019.1604948 
Saraiva, A.M., Castro, R.H.A., Cordeiro, R.P., Peixoto Sobrinho, T.J.S., Castro, V.T.N.A., Amorim, E.L.C., Xavier, H.S. \& Pisciottano, M.N.C. (2011). In vitro evaluation of antioxidant, antimicrobial and toxicity properties of extracts of Schinopsis brasiliensis Engl. (Anacardiaceae). African Journal of Pharmacy and Pharmacology 5: 1724-1731. https:// doi.org/10.5897/AJPP11.428

Sati, O.P., Chaukiyal, D.C., Nishi, M., Miyahara, K. \& Kawasaki, T. (1986). An iridoid from Randia dumetorum. Phytochemistry 25: 2658-2660. https://doi.org/10.1016/S0031-9422(00) $84532-X$

Shailasree, S., Sampathkumara, K.K., Niranjana, S.R. \& Prakash, H.S. (2014). Bioactive potential of medicinal plants from Western Ghats region, India. Journal of Herbs, Spices and Medicinal Plants 20: 221-234. https://doi.org/ 10.1080/10496475.2013.860070

Singh, I. (2017). Antimicrobials in higher plants: classification, mode of action and bioactivities. Chemical Biology Letters 4: 48-62.

Singh, S.K., Patwa, D.K., Tilak, R., Das, A. \& Singh, T.B. (2019). In vitro susceptibility of dermatophytes to oral antifungal drugs and amphotericin B in Uttar Pradesh, India. Indian Journal of Dermatology, Venereology and Leprology 85: 388392. https://doi.org/10.4103/ijdvl.IJDVL_319_18

Sit, N.W., Chan, Y.S., Chuah, B.L., Cheng, R.J., Leong, W.M. \& Khoo, K.S. (2017). Antiviral, antifungal and antibacterial activities of the Chinese medicinal plants, Houttuynia cordata, Lobelia chinensis and Selaginella uncinata. Southeast Asian Journal of Tropical Medicine and Public Health 48: 616627.
Sivagurunathan, A., Packiam, K.M. \& Innocent, B.X. (2015). Evaluation of antimicrobial potential of chosen plants. World Journal of Pharmaceutical Research 4: 970-978.

Tan, J.B.L., Lim, Y.Y. \& Lee, S.M. (2015). Antioxidant and antibacterial activity of Rhoeo spathacea (Swartz) Stearn leaves. Journal of Food Science and Technology 52: 2394-2400. https://doi.org/10.1007/s13197-013-1236-z

Tasiam, E., Primaharinastiti, R. \& Ekasari, W. (2020). In vitro antimalarial activity and toxicity studies of Johar (Cassia siamea) leaves from three different locations. African Journal of Infectious Diseases 14: 23-29.

Taylor, R.S.L., Hudson, J.B., Manandhar, N.P. \& Towers, G.H.N. (1996). Antiviral activities of medicinal plants of southern Nepal. Journal of Ethnopharmacology 53: 105-110. https:// doi.org/10.1016/S0378-8741(96)01430-4

Vallabhaneni, S., Mody, R.K., Walker, T. \& Chiller, T. (2016). The global burden of fungal diseases. Infectious Disease Clinics of North America 30: 1-11. https://doi.org/10.1016/ j.idc.2015.10.004

Thomas, W., Merish, S. \& Tamizhamuthu, M. (2014). Review of Alternanthera sessilis with reference to traditional Siddha medicine. International Journal of Pharmacognosy and Phytochemical Research 6: 249-254.

World Flora Online Consortium (2020). World flora online. http://www.worldfloraonline.org. Accessed 11 October 2020. 